\title{
Interest group influence in micro-states: the role of networking skills
}

Direnç Kanol, University of Siena, Italy

\begin{abstract}
This paper argues that an interest group's networking skills in micro-states may be as important, if not more important than other variables discussed in the interest group influence literature. This argument is based on the recent literature on democratisation in micro-states which shows that politics in these states is personalistic in nature. The argument is supported by expert interviews undertaken in the Republic of Cyprus and the Turkish Republic of Northern Cyprus.
\end{abstract}

\section{JEL classification}

D72; D73, D74.

\section{Keywords}

Cyprus; interest groups; interest group influence; lobbying; micro-states; networking skills. 


\section{Introduction}

What determines interest group influence? This question is crucial to all who value democracy. In theory, one-person, one-vote rule should ensure that each citizen has an equal say in public policy. This is, however, far from the truth. Organised interests try to influence policy and at times, they achieve their goals. Hence, the public policy literature focuses on how influential organised interests are and why one group may be influential whereas another may not be. The predominant belief in the literature is that providing information and offering citizen-support to the policy-makers enable interest groups to exert influence. The level of influence also depends on the preferences of the policy-makers, public opinion and issue salience. Interest group literature, however, does not pay enough attention to the role of networking skills. This paper argues that an interest group's networking skills may be as important, if not more important than other variables discussed in the interest group literature. This argument is based on the recent literature on democratisation in micro-states which shows that politics in these states are personalistic in nature. Personal ties are crucial for getting things done. The argument is supported by empirical evidence gathered from expert interviews in the Republic of Cyprus and the Turkish Republic of Northern Cyprus. The following section reviews the interest group literature and shows that the role of networking skills as a determinant of influence is critically under-researched. The section after that describes the nature of politics in micro-states and generates a proposition regarding interest group influence in these states. After discussing the method and presenting the findings from the in-depth interviews, the final part discusses the implications of this study.

\section{Interest Group Influence: A Literature Review}

Some authors argue that interest groups lobby 'friendly' legislators, those who already agree with them, and the legislators use the interest groups to acquire much needed information to attain their goals (Bauer et al, 1963; Milbrath, 1963). This view has been criticised by some who suggest that lobbying sympathisers serves only to counteract the effect of other groups trying to push the policy in the opposite direction, and lobbying 'foes' is not an exception but a norm (AustenSmith and Wright, 1994). Also, we should not forget that there are a significant number of scholars who argue that lobbying 'swing' legislators is also common (Smith, 1984; Wright, 1990; Schlozman and Tierney, 1986). If the first group of authors is right, this either means that interest groups are mere information conveyors to policy-makers and they do not exert much influence on policy-makers (Hall and Wayman, 1990) or they select to convey information to 'friends' in power in order to achieve their own objectives that is congruent with the public actors' objectives (Hall and Deardorff, 2006).

Although the nature of interest group influence is still a puzzle, exploring the determinants of interest group influence is equally important. The most parsimonious theory that can be used to explain the relationship between interest groups and decision-makers to date is the resource dependence theory. The roots of this theory can be found in the work of the sociologists Levine and White (1961). An important extension to the resource dependence perspective was presented by Pfeffer and Salancik (2003). Studying health organisations, Levine and White (1961) argued that no organisation is able to control all the resources it needs to achieve its goals. This is why organisations are dependent on other organisations to accomplish their tasks (Levine and White, 1961). According to Pfeffer and Salancik (2003), interdependence is the key word for explaining exchange between organisations. Dependence of one organisation on another can be measured by the importance of the resource that the organisation receives through interactions with the other, measured in turn by the relative magnitude and the nature of the resource (Pfeffer and Salancik, 2003). If an organisation absolutely needs a certain 
type of resource to attain its goals, then this resource is essential for that organisation (Pfeffer and Salancik, 2003). Dependence on the environment refers to the importance of the resource to the organisation demanding that resource as well as the availability of the resource from other sources (Jacobs, 1974; Pfeffer and Salancik, 2003). Based on this understanding, one may argue that organisations are expected to be more responsive to other organisations that control the most problematic/critical resource (Pfeffer and Salancik, 2003).

As a priority, we need to start the discussion about governmental organisations by acknowledging their considerable power when choosing which interest groups to contact and which ones not to contact. Nevertheless, like any other organisation, governmental organisations do not possess all the resources they need to accomplish their tasks. So, it is inevitable that the criticality of the resources possessed by interest groups will have an effect on governmental authorities' decision to engage in resource exchange with these groups. It should come as no surprise that scholars studying access and influence of interest groups to governmental actors have benefited from this theory. Scholars working on the European Union produced interesting research that strived to explain the logic of access and influence by using the resource dependence theory (Bouwen, 2004; Klüver, 2013).

The vast majority of research on interest groups concentrates on the power of information as a determinant of influence regardless of the method or discipline. We can speak of two types of information: political information and technical information. Plausibly, most technical information would also entail some political aspects but what matters is that technical information gives predictions about policy consequences in the technical sense. Political information, on the other hand, is about signalling mobilisation consequences of the group or other groups as a result of an action that could be taken by a policy-maker (Heitshusen, 2000, Potters and van Winden, 1992; Austen-Smith, 1998). Governmental officials' time is restricted and they are neither able nor willing to give access and influence to each and every interest group. In line with the resource dependence theory, one can argue that policy-makers grant access and influence to informative groups (Reenock and Gerber, 2008; Crombez, 2002; Bouwen, 2004; Klüver, 2013).

Another crucial resource is citizen-support (Klüver, 2013). Policy-makers try to understand the magnitude of support for or opposition against a policy-proposal because if policy-makers enact laws that are highly unpopular, they pay for this in the next election (Kingdon, 1995; Fiorina, 1989; Mayhew, 1974; Arnold, 1990). With re-election prospects in mind, public actors look to have the endorsement of organisations with the support of a sizeable number of citizens (Klüver, 2013). Therefore, based on the resource dependence perspective, citizen support can be interpreted as a good for access and influence where electoral support is the causal mechanism that gives meaning to this relationship. Citizen support does not only affect the politicians with the ambition to get re-elected but also the bureaucrats. Despite the fact that bureaucrats may have more manoeuvring space as they do not run in the elections, they look for public endorsement and legitimacy (Poppelaars, 2009). The higher the support of citizens an organisation has that gives its endorsement to a bureaucrat, the higher the perceived legitimacy of that bureaucrat will be. Therefore, citizen support is also expected to affect bureaucrats as well as politicians.

Although resource dependence theory suggests a parsimonious framework for explaining influence, we cannot oversee the varying nature of political context and its impact on the opportunity to exert influence. Political opportunity structures (Kitschelt, 1986; Meyer and Minkoff, 2004) and political mediation (Amenta et al, 1992; Amenta et al, 1994; Amenta et al, 2005) theories that were developed by scholars studying social movements took this aspect into account and suggested that the characteristics of the political system and the politicians have a considerable amount of impact on social movement outcomes. Various studies 
show that interest groups are more likely to exert influence, for instance, when the politicians are friendlier towards the cause of the lobbyists (Kriesi et al, 1995; Giugni, 2004; 2007; Soule and Olzak, 2004; McVeigh et al, 2003). This finding suggests that interest group influence also depends on which politicians are in power and interest groups may have to adjust their strategies depending on the political context.

Public opinion is also important. Re-election motivated politicians take what the public thinks about a certain issue and how strongly they feel about this issue into account (Kingdon, 1995; Fiorina, 1989; Mayhew, 1974; Arnold, 1990). There are mixed findings in the literature. Some research found that policy-makers are not responsive to public opinion (Jacobs and Shapiro, 2000; 2002; Cohen, 1997). However, the predominant belief in the literature based on empirical findings is that public opinion matters. Politicians are more likely to pass laws that are popular (Page and Shapiro, 1983; Burstein, 2003; Erikson et al, 2002; Monroe, 1998; Lax and Phillips, 2009). A lobbyist that advocates an issue that is clearly opposed by the public may not have much success.

We should also take issue salience into account. Baumgartner et al (2009) argues that most issues do not find a place on the agenda of the policy-makers. Policymaking process does not resemble an incrementalist one as Lindblom (1959) argued. According to Lindblom (1959), the policy-making process involves many actors and moves in small steps. A rather recent major work shows that this argument could be false (Baumgartner et al, 2009). Baumgartner et al's (2009) results are based on Baumgartner and Jones' (1993) punctuated-equilibrium model which argues that most issues remain stable for most of the time, and where policy-change occurs, it follows a pattern that is contrary to the logic of incrementalism. Policy-change occurs very rapidly in few issue areas (Baumgartner and Jones 1993). Salience of an issue may have a positive impact on the likelihood of an interest group's success in exerting influence on the policy agenda (Burstein, 1981; Page and Shapiro, 1983; Haider-Markel, 1996; 2003). Once an issue becomes very salient and is placed on the political agenda, we may observe a rapid change of policy.

What is clearly lacking in the interest group influence literature is a discussion about the role of networking skills. The role of networking skills is only very indirectly mentioned in a few studies such as Carpenter et al (1998), who argue that interest groups exist in a network. A group which possesses weak ties with a sizeable number of groups in this network is able to receive and convey information, which in turn, provides it access to the governmental actors. Heaney (2006) shows that playing a brokerage role between disconnected lobbying coalitions and political parties enhances a group's influence in the policy-making process. Finally, Beyers and Braun (2014) argue that an interest group's ability to bridge different coalitions increases its chances of gaining access to the policymakers. However, none of these studies directly deal with the capacity of the individuals within interest groups to establish direct relationships with the policymakers.

\section{The Nature of Politics in Micro-states and its Implications for Interest Group Influence}

Different authors used different population sizes to define which states can be defined as micro-states (Anckar, 2010). Using certain numbers, however, can be problematic. Consider, for instance, that we use 500.000 people as a ceiling to determine if a state is indeed a micro-state or not. Can we really assume that theoretical arguments that apply to a country of 490.000 people do not apply to a country of 510.000 people? This paper uses a more deductive approach to defining micro-states that serve the topical purpose of this paper. A micro-state is a very small country with a very small number of population size and with a very large 
number of people knowing a large part of the rest of the population. The proverbial 'everyone knows everyone' is a crucial definition of the social and political life in micro-states. This deductive understanding would corroborate with the classification schemes of scholars who keep Fiji with a population of 780.000 within the discussion about micro-states but exclude Papua New Guinea, with a population of 4 million (Anckar, 2002a). Anckar (2003; 2008) uses the 1 million ceiling and suggests that there are 42 micro-states in the world. Therefore, the small size of these states should not mean that careful inquiries about their society and politics can be neglected.

Unlike the earlier studies which suggested that smallness is good for democracy (Dahl and Tufte, 1973; Hadenius, 1992; Srebrnik, 2004), the recent literature suggests that the relationship between smallness and democracy is ambiguous at best and small size may, in fact, have a negative effect on the quality of democracy (Veenendaal, 2013a; 2013b; 2013c; Corbett, 2013). The earlier literature points to homogeneity, a sense of fellowship and community, a lack of complexity in solving social and political issues, and the proximity between the rulers and the citizens as mechanisms to establish a positive link between smallness and quality of democracy (Dahl and Tufte, 1973; Ott, 2000; Anckar, 2002a; 2002b). The recent literature, however, suggests that politics in micro-states is more 'informal' in nature. Almost everything depends on personal relationships. Obligations to family and kin precedes the obligations to the society as a whole (Corbett, 2013). Thus, civic culture and social capital, which are argued to be essential parts of embedded democracies are not found in micro-states. The proximity between the rulers and the citizens which is argued to be a boon can actually be a bane. Consider, for instance, the decision-making process for public appointments. It is very hard for the elected officials to be impartial when family, kin and friends are extremely important in social life and when there are many individuals that could be classified as either of these three. It is, also, almost impossible to avoid people one falls apart with. Therefore, elected officials try to live up to the expectations of their close ones and acquaintances and the citizens try to keep good relationships with their government at all times. Politics is conducted outside of the public domain. This causes issues with nepotism and clientelism (Corbett, 2013; Veenendaal, 2013a; 2013c).

If politics in micro-states is personalistic in nature, then the organised interests should master the art of establishing personal relationships, in order to exert influence on the policy-making process. In these states, who you know may be much more important than what you know (information), which runs counter to the decades of theorising in the interest group literature. Networking skills, therefore, may be particularly important for exerting influence in micro-states. By networking skills, I mean the ability of an individual to meet and establish good contacts with the governmental actors. A person may have the intellectual resources to generate and provide information to the governmental actors. However, this does not mean that he/she has the skills to establish weak or strong ties with these governmental actors. Once a relationship between an interest group and a governmental actor is established, interest groups can ask for 'favours' from their contacts in governmental posts which is shown to be the main form of policy-making in the highly personalistic and clientelistic political decision-making process in microstates. Therefore, networking skills are expected to be a strong determinant of interest group influence in micro-states.

\section{Method}

Expert-interviewing is a valuable technique when it comes to discovering what affects interest group influence. Influence is the primary goal of lobbying. By practicing lobbying for long years, experts learn what works, what does not work and why. Therefore, they are in a good position to suggest what tactics work and what the exogenous factors that may affect their influence may be. Different 
interest groups may have different opinions about these exogenous factors. The goal of expert-interviewing method is not to get as many interviews as possible, but to get as many interviews from people who have the most in-depth information as possible. Therefore, a policy field is chosen first and the names of the organisations that have the most in-depth information about how to exert influence are obtained.

The Civil Society Organisations Directory (2011) provides a good source to obtain the emails of a population of interest groups, both in the Republic of Cyprus and the Turkish Republic of Northern Cyprus on the island of Cyprus. The Republic of Cyprus was established in 1960 as a partnership state between the Greek Cypriots and the Turkish Cypriots. After civil and political conflict intensified between these two communities, it has become a Greek Cypriot state in 1963. The Turkish Republic of Northern Cyprus was established in 1983. However, it is only recognised by Turkey which makes it fall under the de facto state classification. These are micro-states with population sizes of 862,000 (Statistical Service of the Republic of Cyprus, 2011) and 294,906 (Devlet Planlama Örgütü, 2011) respectively. Therefore, concentrating on lobbying in these two states offers an opportunity to analyse the potential impact of networking skills for exerting influence in micro-states. I focused on the field of peacebuilding for the purposes of this paper since the experts in this field could be identified easily. A list of the population of organisations that potentially deal with peace related issues during the months of July and August 2012 is created. From August 2012 to October 2012, I conducted a survey that asked these organisations to name 3 well known peacebuilding organisations that are active in Cyprus in order increase the number of observations. It should be stressed that an interest group in this paper refers to any non-governmental group that tries to influence public policy either by inside lobbying or outside lobbying tactics. Therefore, Non-Governmental Organisations (NGOs) which engage in lobbying the governmental actors classify as interest groups.

Overall, 41 civil society organisations were found to be active in the field of peacebuilding with varying degrees of intensity. These organisations were emailed a questionnaire followed by a reminder email in case no response after a month. 25 organisations replied to the emails with a response rate of 61 percent. These organisations were asked if they were able to initiate contact with the decisionmakers at the governmental level face-to-face, via internet, phone or by other similar means in order to promote peace in the last year. Out of these 25 organisations that responded to the survey, 14 of them answered 'yes' to this question. Considering also the list of organisations that were named by other organisations as one of the 3 well known peacebuilding organisations, 6 peacebuilding organisations out of these 14 organisations were identified as true experts in the field of peace lobbying. ${ }^{1}$ I also included a Turkish Cypriot policymaker in the sample who was responsible for deciding the main aspects of the peace negotiations with the Greek Cypriots. Kudret Özersay, the chief Turkish Cypriot negotiator responsible for the negotiations with the Greek Cypriots from April 2010 to June 2012 was included in the sample as an expert policy-maker who is not a lobbyist but has expert knowledge on lobbying. Özersay was lobbied by various organisations with respect to the reunification/peace issue. Managers and/or project managers of these organisations and the policy-maker were interviewed face to face with the open-ended interview method. They were asked about the possible ways to gain influence and prompts and probes were posed depending on the discussion that took place. Interviews lasted approximately 30

\footnotetext{
${ }^{1}$ These organisations are: Association for Historical Dialogue and Research, The Management Centre of the Mediterranean, NGO Support-Centre, Cyprus Academic Dialogue, Cyprus 2015 and The Cyprus Community Media Centre.
} 
minutes on average. The interviewees agreed to be recorded and identified for the academic purposes of this project.

\title{
Results
}

In this section, the findings from the interviews are presented. Evidence for the factors that were discussed in the literature review section are presented under separate sub-headings. The role of networking skills is discussed at the end of this section.

\section{Information}

The experts suggested that the main factors discussed in the literature are all relevant. Findings from the in-depth interviews provide evidence for the value of conveying information to the policy-makers. The common viewpoint of the interviewees is that technical information that could be of use to the policy-makers can make a big difference. In line with the resource dependence theory, the consensus is that the type of information matters. If peacebuilding organisations possess information that is valuable to the policy-makers and if it cannot be offered to them by other sources, the likelihood of influence increases. The experts suggested that providing information to the policy-makers is very important for gaining access. They also believe that it can increase the likelihood of exerting influence:

\begin{abstract}
Even the policy-makers at the highest levels whom you might assume to have a network of people supplying them information, they are not aware of certain things... They do not know... So if you give them information that they did not know about, they may realise the usefulness of this information. Let me give you an example... We did research on teachers' perception on history teaching about three years ago and we found out that teachers were positive towards reform in history teaching. The policy-makers, on the other hand, thought on the contrary. So, they were afraid of something that did not exist. If you can bring new information in a rather scientific or objective way, you have the space to influence the policy-maker during the interaction process. (Expert 1)

From our experience, I think the more you contribute to the immediate interest of the decisionmakers, the more access and influence you will have. So if you are giving them something they can use and this is something they don't have and they find this valuable, then the relationship becomes more of a mutual benefit kind. Why do we have access as Cyprus 2015? Because we say listen; if you give up Güzelyurt (Morphou) or Maraş (Varosha), this is how much reaction you will get, or if you accept more than fifty thousand people of Turkish origin to become citizens of a united Cyprus, this is how much reaction you will get. How many Greek Cypriots will accept, not to be reinstated to their old properties? This is very valuable information... Decision-makers need information. We try to bring expert knowledge to the attention of the policy-makers that they usually lack because they are surrounded by people who are not really experts... This can be technical or political information but information should be relevant with the needs of the policy-makers. (Expert 2)
\end{abstract}

\section{Citizen Support}

Information, however, is not the only thing the policy-makers need. Politicians need votes. In other words, they need citizen support. Bureaucrats need legitimacy and they get this via citizen support as well. How many members a peacebuilding organisation is representing or how many people can it mobilise? These are very important questions. The interviewees suggest that citizen support is pivotal for exerting influence:

Because the number of members an organisation is representing means votes for them, when the politicians are judging whether they should give you an appointment or take your ideas into consideration, they always ask themselves; 'I am going to give him my half an hour or so; in return, what am I going to get from this guy? First, I can gain some information, but secondly and sometimes more importantly, it is very important for me to accept this guy because he may be representing 1,000 votes. I have to take him into consideration!. (Expert 3) 


\title{
Political Allies
}

Although the exchange argument may be valid, we should also consider that influence is decided by exogenous political factors. The experts were of the same opinion that it is much more difficult to convince policy-makers that have a more ethno-nationalist approach to the Cyprus problem. Similarly, influence is limited when peace-building organisations lobby the policy-makers that are not favourably disposed toward civil society participation in the policy-making process. This argument is in line with the political opportunity structures and political mediation theories that argue that having political allies increases the likelihood of influence:

\begin{abstract}
Naturally, the 'leftist' policy-makers that work on reconciliation are more inclined to listen to us. I'd lobby both friendly and non-friendly politicians though. Because, in fact, you would need a good mix of people. The positive ones will most likely take you further. The negative ones, on the other hand, if you never approach them, then you would never have a chance to have an attempt to convert them. (Expert 4)

When you have a certain character who is negative towards civil society participation in policy-making and sees you as a nuisance and thinks that you are rocking the boat, he/she is going to shy away from you and it will be much harder to deal with him/her. (Expert 5)
\end{abstract}

\section{Public Opinion}

The experts also mentioned the possible impact of public opinion. Based on the findings in the literature, it is expected that if public opinion is not in line with the demands of the peacebuilding organisations, then these organisations are less likely to be able to exert influence. Interviewees suggest that this may be the case. However, what is clear is that most issues that the lobbyists work on are more technical in nature and the preferences of the policy-maker himself/herself, irrespective of the public opinion, could be a more decisive exogenous factor that determines if influence takes place or not:

Of course, politicians, who want to be re-elected are not going to tell you 'yes' if you want something that a large number of voters are against. But there are ways around this. Many times, we work on small technical issues that do not catch the eye of the public. Therefore, politicians are less concerned with the public opinion in such cases. (Expert 3)

\section{Issue Salience}

Regarding issue salience and the likelihood of success, some interviewees suggested that lobbyists are more likely to be successful when there is a dynamic for resolving the problem at the highest political level. When there are some prospects with respect to the solution of the Cyprus problem and the issue is salient, policy-makers are more likely to be willing to engage with the lobbyists:

\footnotetext{
One very important issue is the general conjecture that you are living in. For example, if there is a situation when the reconciliation issue is becoming quite hot in the sense that we are at a stage of critical point in the negotiation process, it affects your work. In those times, peace issue occupies a very high spot on the agenda of the policy-makers and it is easier to influence those people because all of a sudden, they start thinking about reconciliation and peace and they want some ideas or some technical knowledge. When there is no possibility and everybody is very pessimistic about things, policy-makers just put the issue at the bottom of their agenda and they don't want to hear anything about it. (Expert 3)
}

\section{Networking Skills}

The experts, however, stressed that none of these variables may be as important as networking skills. In a small country, it is very important that people know the policy-makers. Most individuals working for powerful interest groups have at least a few contacts, controlling the gates of political power. Personal relationships make access and influence much more likely. It is much easier to establish long-term relationships with the governmental actors and ask for certain policies to be enacted if one possesses the skills to establish these contacts. Interest group literature does not pay enough attention to the role of networking skills. The 
following quotations provide evidence for the critical nature of personal relationships and the skills to establish these relationships:

Personal contacts are very important. It is easier for the civil society representatives who know people to access the authorities and it is easier for the authorities to have access to civil society as well. (Expert 6)

I am an academic myself, and I happen to know the Cyprus problem quite well, let's say, since this is my research area and all that, I have a specific name that some people know, especially by the decision-makers. Then, for example, I, as a member of a CSO, if I want to have access, to want to go and see, to talk to a decision-maker, compared to somebody, let's say an assistant at the Eastern Mediterranean University, of course, it makes a very big difference. (Expert 2)

I mean networking is an issue here ok... So, if an ex-policy maker establishes an NGO then obviously, he knows the channels or she knows the channels and she knows how to make a move and hence that NGO has ... I'm giving an extreme situation... Let's say two academics and two politicians and two business advisors get together and form an NGO then that becomes a very strong structure immediately. Because there is enough weight and networking substance that will increase access and influence. So by extension, networking is very important. (Expert 4)

I would stress the word capacity because you might have a hundred staff and not one of them may have the capacity to exert influence. You know when we talk about capacity you are also talking about people having good networks, not just their education and experience, but you know they might have good networks and you know they can pull the strings, this is quite important. (Expert 3)

\section{Discussion and Conclusion}

This paper argues that networking skills are an important determinant of interest group influence in micro-states. Since the role of networking skills is underresearched, the paper aimed to contribute to the literature on the determinants of interest group influence by providing evidence from the interviews undertaken in the Republic of Cyprus and the Turkish Republic of Northern Cyprus. The qualitative data obtained from peace advocacy experts in these two states provided some evidence for this hypothesis.

A couple of points should be made for guiding future research on this topic. Expert interviews conducted for this paper provided valuable evidence for the role of networking skills in the influence game. However, the absence of expert interview data from large states prevented testing a possible difference between interest group influence in micro-states and large states. Networking skills may actually be more valuable for exerting influence in micro-states than large states when the highly personalistic nature of politics in micro-states is taken into consideration. Future research could benefit from a Most Similar Systems Design (MSSD) analysis and conduct a larger number of interviews both from a micro-state and a large state to see if networking skills are significantly more important for influencing political actors in micro-states than in large states.

A careful reader may also question if the personalistic and clientelistic nature of politics in the Republic of Cyprus and the Turkish Republic of Northern Cyprus is indeed due to its smallness rather than other factors. After all, it is a fact that the countries in Southern Europe show similar political characteristics with these two micro-states when compared to the Northern European countries. There is, however, much evidence that can suggest that smallness of these two states has an independent effect other than the geographical location of these micro-states. This is due to the opportunity available for us to compare the nature of politics in other micro-states with the two micro-states analysed in this paper. Brilliant indepth research from micro-states all over the world suggest that similar phenomena exist in most micro-states in regard to the political process (see Corbett, 2013; Veenendaal, 2013a; 2013b; 2013c).

At the expense of sounding tautological, it should be stressed that more research in different countries and other policy areas is needed to substantiate the argument 
put forward. Nevertheless, this study aims to contribute to the literature on interest group influence and the nature of politics in micro-states.

\section{References}

Amenta, Edwin, Neal Caren, Elisabeth Chiarello and Yang Su (2010) 'The Political Consequences of Social Movements', Annual Review of Sociology 36: 287-307.

Amenta, Edwin, Neal Caren, and Sheera Joy Olasky (2005) 'Age for Leisure? Political Mediation and the Impact of the Pension Movement on US Old-Age Policy', American Sociological Review 70 (3): 516-538.

Amenta, Edwin, Bruce G. Carruthers and Yvonne Zylan (1992) 'A Hero for the Aged? The Townsend Movement, the Political Mediation Model, and US Old-Age Policy, 1934-1950', American Journal of Sociology 98 (2): 308-339.

Amenta, Edwin, Kathleen Dunleavy and Mary Bernstein (1994) 'Stolen Thunder? Huey Long's "Share Our Wealth," Political Mediation, and the Second New Deal', American Sociological Review 59 (5): 678-702.

Anckar, Dag (2002a) 'Democratic Standard and Performance in Twelve Pacific Micro-states', Pacific Affairs 75 (2): 207-225.

Anckar, Dag (2002b) 'Why are Small Island States Democracies?'. The Round Table: The Commonwealth Journal of International Affairs: 91 (365): 375-390.

Anckar, Dag (2003) 'Direct Democracy in Microstates and Small Island States', World Develpment 32(2): 379-390.

Anckar, Dag (2008). 'Microstate Democracy: Majority or Consensus; Diffusion or Problem-Solving?', Democratization 15(1): 67-85.

Anckar, Dag (2010) 'Small is Democratic, But Who is Small?', Arts and Social Sciences Journal: 1-10.

Arnold, R. Douglas (1990) The Logic of Congressional Action. New Haven: Yale University Press.

Austen-Smith, David (1998) 'Allocating Access for Information Contributions', Journal of Law, Economics and Organization 14 (2): 277-303.

Austen-Smith, David and John R. Wright (1994) 'Counteractive Lobbying', American Journal of Political Science 38 (1): 25-44.

Bauer, Raymond A., Ithiel de la Sola Pool and Lewis A. Dexter (1963) American Business and Public Policy: The Politics of Foreign Trade. New York: Atherton Press.

Beyers, Jan and Caelesta Braun (2014) 'Ties that count: Explaining interest group acces to policymakers', Journal of Public Policy 34(1): 93-121.

Baumgartner, Frank R., Jeffrey Berry, Marie Hojnacki, David C. Kimball and Beth L. Leech (2009) Lobbying and Policy Change: Who Wins, Who Loses, and Why. Chicago: University of Chicago Press.

Baumgartner, Frank R. and Bryan D. Jones (1993) Agendas and Instability in American Politics. Chicago: University of Chicago Press.

Bouwen, Pieter (2004) 'Exchanging Access Goods for Access: A Comparative Study of Business Lobbying in the European Union Institutions', European Journal of Political Research 43 (3): 337-369.

Burstein, Paul (1981) 'The Sociology of Democratic Politics and Government', Annual Review of Sociology 7: 291-319.

Burstein, Paul (2003) 'The Impact of Public Opinion on Public Policy: A Review and an Agenda' Political Research Quarterly 56 (1): 29-40. 
Carpenter, Daniel P., Kevin M. Esterling and David M. J. Lazer (1998) 'The Strength of Weak Ties in Lobbying Networks: Evidence from Health-Care Politics in the United States', Journal of Theoretical Politics 10(4): 417-44.

Civil Society Organizations Directory. (2011). The Management Centre of the Mediterranean and the NGO Support Centre. URL (consulted on 05.07.2012) http://www.csodirectory-cyprus.eu/.

Cohen, Jeffrey E. (1997) Presidential Responsiveness and Public-Policy Making. Ann Arbor: The University of Michigan Press.

Corbett, Jack (2013) 'Everybody knows Everybody: Practicing Politics in the Pacific Islands'.Democratization DOI:10.1080/13510347.2013.811233.

Crombez, Christophe (2002) 'Information, Lobbying and the Legislative Process in the European Union', European Union Politics 3 (1): 7-32.

Dahl, Robert Alan and Edward R. Tufte (1973) Size and Democracy. Stanford: Stanford University Press.

Devlet Planlama Örgütü (2011) KKTC Nüfus ve Konut Sayımı. URL (Consulted 09.03.2014) http://www.devplan.org/Nufus-2011/nufus\%20son_.pdf.

Erikson, Robert, S., Michael B.MacKuen and James A.Stimson (2002) The Macro Polity. New York: Cambridge University Press.

Fiorina, Morris P. (1989) Congress: Keystone of Washington Establishment. New Haven: Yale University Press.

Giugni, Marco (2004) Social Protest and Policy Change: Ecology, Antinuclear, and Peace Movements in Comparative Perspective. Lanham, MD: Rowman \& Littlefield.

Giugni, Marco (2007) 'Useless Protest? A Time-Series Analysis of the Policy Outcomes of Ecology, Antinuclear, and Peace Movements in the United States, 1977-1995', Mobilization: An International Quarterly 12 (1): 53-77.

Hadenius, Axel (1992). Democracy and Development. Cambridge: Cambridge University Press.

Haider-Markel, Donald P. and Kenneth J. Meier (1996) 'The Politics of Gay and Lesbian Rights: Expanding the Scope of Conflict', The Journal of Politics 58 (2): 332-349.

Haider-Markel, Donald P. and Kenneth J. Meier, (2003) 'Legislative Victory, Electoral Uncertainty: Explaining Outcomes in the Battles over Lesbian and Civil Rights', Review of Policy Research 20 (4): 671-690.

Hall, Richard L. and Alan V. Deardorff, (2006) 'Lobbying as Legislative Subsidy', American Political Science Review 100 (1): 69-84.

Hall, Richard L. and Frank W. Wayman (1990) 'Buying Time: Moneyed Interests and the Mobilization of Bias in Congressional Committees'. American Political Science Review 84 (3): 797-820.

Heaney, Michael T. (2006) 'Brokering health policy: Coalitions, parties, and interest group influence', Journal of Health Politics, Policy and Law 31(5): 887-944.

Heitshusen, Valerie (2000) 'Interest Group Lobbying and US House Decentralization: Linking Informational Focus to Committee Hearing Appearances', Political Research Quarterly 53 (1): 151-176.

Jacobs, David (1974) 'Dependency and Vulnerability: An Exchange Approach to the Control of Organizations', Administrative Science Quarterly 19 (1): 45-59. 
Jacobs, Lawrence R. and Robert Y. Shapiro (2000) Politicians Don't Pander: Political Manipulation and the Loss of Democratic Responsiveness. Chicago: Chicago University Press.

Jacobs, Lawrence R. and Robert Y. Shapiro (2002) 'Politics and Policymaking in the Real World: Crafted Talk and the Loss of Democratic Responsiveness', in Jeff Manza, Fay Lomax Cook, and Benjamin I. Page (eds) Navigating Public Opinion: Polls, Policy and the Future of American Democracy. Oxford, Oxford University Press, pp. 54-75.

Kingdon, John W. (1995) Agendas, Alternatives, and Public Policies. New York: Harper Collins.

Kitschelt, Herbert (1986) 'Political Opportunity Structures and Political Protest: AntiNuclear Movements in Four Democracies'. British Journal of Political Science 16 (1): $57-85$.

Klüver, Heike (2013) Lobbying in the European Union: interest groups, lobbying coalitions, and policy change. Oxford: Oxford University Press.

Kriesi, Hanspeter., Ruud Koopmans, Jan Willem Duyvendak and Marco G. Giugni (1995) The Politics of New Social Movements in Western Europe. A Comparative Analysis. London: University of Minnesota.

Lax, Jeffrey R.and Justin H. Phillips (2009) 'Gay Rights in the States: Public Opinion and Policy Responsiveness', American Political Science Review 103 (3): 367-386.

Levine, Sol and Paul E. White (1961) 'Exchange as a Conceptual Framework for the Study of Interorganizational Relationships', Administrative Science Quarterly 5 (4): 583-601.

Lindblom, Charles E. (1959) 'The science of "muddling through"'. Public Administration Review, 9(2): 79-88.

Mayhew, David R. (1974) Congress: The Electoral Connection. New Haven, CT: Yale University Press.

McVeigh, Rory, Michael R. Welch and Thoroddur Bjarnason (2003) 'Hate Crime Reporting as a Successful Social Movement Outcome', American Sociological Review 68 (6): 843-867.

Meyer, David S. and Debra C. Minkoff(2004) 'Conceptualizing Political Opportunity', Social Forces 82 (4): 1457-1492.

Milbrath, Lester W. (1963) The Washington Lobbyists. Chicago: Rand-MacNally.

Monroe, Alan D. (1998) 'Public Opinion and Policy, 1980-1993'. Public Opinion Quarterly 62 (1): 6-28.

Ott, Dana (2000). Small is Democratic: An Examination of State Size and Democratic Development. New York: Garland.

Page, Benjamin I. and Robert Y. Shapiro (1983) 'Effects of Public Opinion on Policy', American Political Science Review 77 (1): 175-190.

Pfeffer, Jeffrey and Gerald R. Salancik (2003) The External Control of Organizations: A Resource Dependence Perspective. Stanford: Stanford University Press.

Poppelaars, Caelesta (2009) Steering a Course between Friends and Foes: Why Bureaucrats Interest with Interest Groups. Delft: Eburon.

Potters, Jan and Frans van Winden (1992) 'Lobbying and Asymmetric Information', Public Choice 74 (3): 269-292. 
Reenock, Christopher M. and Brian J. Gerber (2008) 'Political Insulation, Information Exchange, and Interest Group Access to the Bureaucracy', Journal of Public Administration Research and Theory 18 (3): 415-440.

Schlozman, Kay Lehman and John T. Tierney (1986) Organized Interests and American Democracy. New York: Harper Collins.

Smith, Richard A. (1984) 'Advocacy, Interpretation, and Influence in the U.S. Congress', American Political Science Review 78 (1): 44-63.

Soule, Sarah A. and Susan Olzak (2004) 'When do Movements Matter? The Politics of Contingency and the Equal Rights Amendment', American Sociological Review 69 (4): 473-497.

Srebrnik, Henry (2004) 'Small Island Nations and Democratic Values', World Development 32(2): 329-341.

Statistical Service of the Republic of Cyprus (2011) New Publication: Demographic Report, 2010-2011. URL (consulted 09.03.2014): http://www.mof.gov.cy/mof/cystat/statistics.nsf/All/C6ECE5795EAC1ED8C2257AB 70038FCD4?OpenDocument\&sub=1\&sel=1\&e=\&print.

Veenendaal, Wouter (2013a) 'Democracy in Microstates: Why Smallness does not Produce a Democratic Political System'. Democratization DOI:10.1080/13510347.2013.820710

Veenendaal, Wouter (2013b) 'Size and Personalistic Politics: Characteristics of Political Competion in Four Microstates', The Round Table: The Commonwealth Journal of International Affairs 102 (3): 245-257.

Veenendaal, Wouter (2013c) 'Size and Institutional Legitimacy: The Case of St Kitts and Nevis', Commonwealth \& Comparative Politics 51 (3): 243-361.

Wright, John R. (1990) 'Contributions, Lobbying and Committee Voting in the U.S. House of Representatives', The American Political Science Review 84 (2): 417438. 